\title{
Arthrogryposis in Murrah buffaloes in southern Brazil 1
}

\author{
Ana Lucia Schild², Mauro P. Soares ${ }^{2}$, Maria C. Damé ${ }^{3}$, Enrique L. Portianski ${ }^{4}$ \\ and Franklin Riet-Correa ${ }^{5}$
}

\begin{abstract}
Schild A.L., Soares M.P., Damé M.C., Portianski E.L. \& Riet-Correa F. 2002. Arthrogryposis in Murrah buffaloes in southern Brazil. $\quad$ Pesquisa Veterinária Brasileira 23(1):1316. Laboratório Regional de Diagnóstico, Faculdade de Veterinária, UFPel, Campus Universitário s/n, Pelotas, RS 96010-960, Brazil.

Congenital arthrogryposis is described in a Murrah buffalo herd. The disease was characterized by curvature and multiple articular rigidity of the hindlimbs or of all limbs without associated defects except for one case of brachygnatia. Histologically there was reduction of motor neurons from the ventral horns of the spinal cord and hypoplasia of the limb muscles. Analysis of the herd breeding records suggests that the disease is genetically transmitted by an autosomal recessive trait.
\end{abstract}

INDEX TERMS: Arthrogryposis, buffalo.

RESUMO -- [Artrogripose em búfalos Murrah no Sul do Rio Grande do Sul, Brasil .] Artrogripose congênita é descrita em um rebanho de búfalos da raça Murrah. A enfermidade caracterizou-se por curvatura e rigidez articular múltipla dos membros posteriores e/ou dos quatro membros sem associação com outros defeitos exceto por um búfalo que apresentou, também, braquignatia. Histologicamente observou-se diminuição dos neurônios motores nos cornos ventrais da medula espinhal e hipoplasia dos músculos dos membros. A análise genealógica dos animais sugere que a doença possa ser geneticamente transmitida por um gene recessivo autossômico.

TERMOS DE INDEXAÇÃ̃: Artrogripose, búfalos.

\section{INTRODUCTION}

Arthrogryposis is a congenital malformation characterized by curvature of the limbs, multiple articular rigidity and muscular dysplasia (Nawrot et al. 1980, Jubb et al. 1993). It is described in humans and in animals including cattle, lambs,

\footnotetext{
${ }^{1}$ Accepted for publication on November 20, 2002.

${ }^{2}$ Laboratório Regional de Diagnóstico, Faculdade de Veterinária, UFPel, Campus Universitário s/n, 96010-900 Pelotas, RS, Brazil.

${ }^{3}$ Centro de Pesquisa Agropecuária de Clima Temperado, 96019-900 Pelotas, RS, Brazil.

${ }^{4}$ Institute of Pathology, School of Veterinary Sciences, National University of La Plata, Calle 60 y 118, CC 296, (1900) La Plata, Buenos Aires, Argentina.

${ }^{5}$ Centro de Saúde e Tecnologia Rural, UFPB, Patos, Paraíba, PB 58700-000.
}

piglets and foals. Kittens and puppies are infrequently affected (Greene et al. 1973, Mayhew 1984, Jubb et al. 1993). The extent of the malformation is variable, involving one, two, three or all four limbs and the axial skeleton. In mild cases two limbs, usually the hind, are fixed in flexion (Jubb et al. 1993).

Arthrogryposis with associated malformations may be hereditary or a phenocopy of the mutant gene(s) effect produced by unknown factors (Nawrot et al. 1980). Homozygosity of a single recessive gene has been proposed as a cause of arthrogryposis in Hereford, Charolais, Jersey and German Black Pied calves (Greene et al. 1973, Nawrot et al. 1980). Arthrogryposis associated with cleft palate was found in several breeds of cattle (Leipold et al. 1970).

The ingestion of Lupinus sericus and Lupinus caudatus between the $40^{\text {th }}$ and $70^{\text {th }}$ day of pregnancy cause arthrogryposis and other malformations in calves. The disease known as crooked calf disease is characterized by flexure of one or more legs and occasionally associated with palatoschisis, torticollis and scoliosis (Shupe et al. 1967).

Outbreaks of arthrogryposis and hydranencephaly in cattle in Australia have been associated with high antibody titres to Akabane virus and to Aino virus (Coverdale 1978, Hartley et al. 1977, Konno et al. 1982). In sheep arthro-gryposis with central nervous system (CNS) malformations has been associated with Cache Valley virus infection in North America (Edwards et al. 1989). Arthrogryposis caused by viral infections is associated with abortion, stillbirth and other malformations such as scoliosis, lumbar lordosis, kyphosis, torticollis and hydranencephaly. Blindness and tongue paralysis are also 
observed depending on the age of the fetus during infection (Konno et al. 1982).

Arthrogryposis of genetic origin is characterized mainly by symmetrical contracture of the four legs. Greene et al. (1973) reported 188 cases of arthogryposis in 1,122 calves from different beef and dairy herds. Most calves had arthrogryposis of the four legs and other associated defects, mainly palatosquisis. In cases of bimelic arthrogryposis no associated defects were observed. In Hereford, Charolais, Jersey and German Black Pied cattle arthrogryposis associated with palatosquisis is caused by a single autosomal recessive gene. Absence of ventral horn cells in the spinal gray matter and neurogenic atrophy of muscle are observed in those calves (Greene et al. 1973).

This report describes the occurrence of arthrogryposis in Murrah buffaloes in southern Brazil.

\section{MATERIALS AND METHODS}

Pathological studies were performed in three affected buffaloes, 2 males and 1 female, which were necropsied. The CNS, fragments of limb muscles and several organs were fixed in $10 \%$ formalin, embedded in paraffin, sectioned at $6 \mu \mathrm{m}$ and stained with hematoxylin and eosin. Fragments of cervical, thoracic and lumbar spinal cord segments of two affected calves were sampled. Five sections of each of these segments were cut at intervals of 2 to $4 \mathrm{~cm}$. One normal newborn buffalo was destroyed and used as control. Immunohistochemical analysis for BVDV was carried out in the CNS fragments of one affected buffalo. Breeding records of 83 cows and 4 bulls from the affected herd were collected at Embrapa-CPACT, Pelotas, Rio Grande do Sul, Brazil.

\section{RESULTS}

The disease was observed in one herd of 83 Murrah buffaloes on a farm in the State of Rio Grande do Sul, southern Brazil. Sixty four cows were sired by 4 bulls, and 19 cows were inseminated with imported semen from Bulgaria. Six (3 females and 3 males) out of 165 calves born in 1995 and 1996 were arthrogrypotic. No disease of viral or bacterial origin has been reported from the herd. None of the cows with deformed calves had received any drugs or other medication during pregnancy. The buffalo herd was kept in grazing areas along with a cattle herd of which no animal was affected.

The arthrogrypotic calves had varying expressions of the defect. Either the hindlimbs alone (bimelic) or all 4 limbs (tetramelic) were affected. There were no other associated congenital defects, except for brachygnathia in one calf. Two affected calves born alive were in sternal recumbency and unable to rise after birth. The remaining calves were born dead, one of them after a distocic delivery. Joint contractures were bilateral; but some differences were observed between limbs, and little passive mobility was possible in the flexed or extended joints (Fig. 1). The lesions were most frequently found in the metacarpophalangeal joints, the elbow, interphalangeal joints of the forelegs and in the metatarsophalangeal joint, followed by the stifle and hock joints of the hindlimbs. In all calves the interphalangeal joints were fixed in the flexed or extended position. One of them had lesions

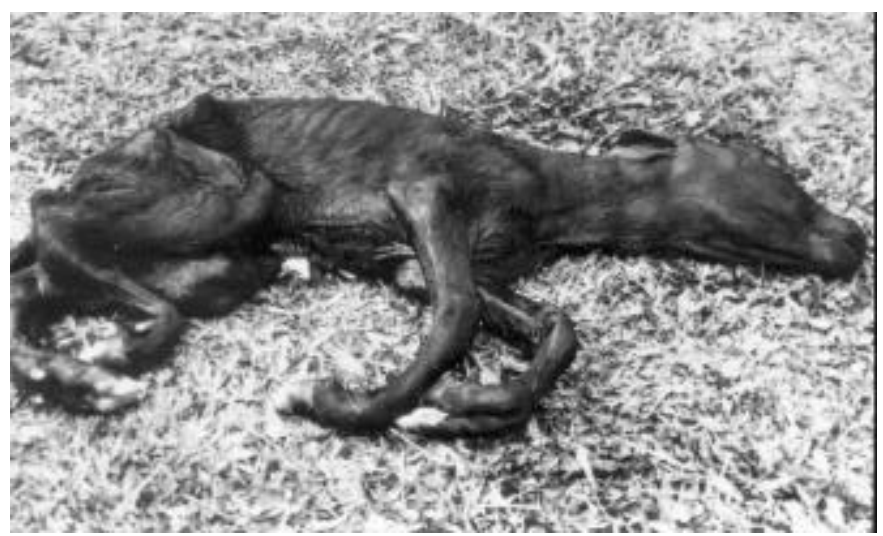

Fig. 1. A newborn buffalo calf with joint contractures in all limbs. The interphalangeal joints of the hindlimbs were fixed in flexed and extended position. Note the scant muscle development.

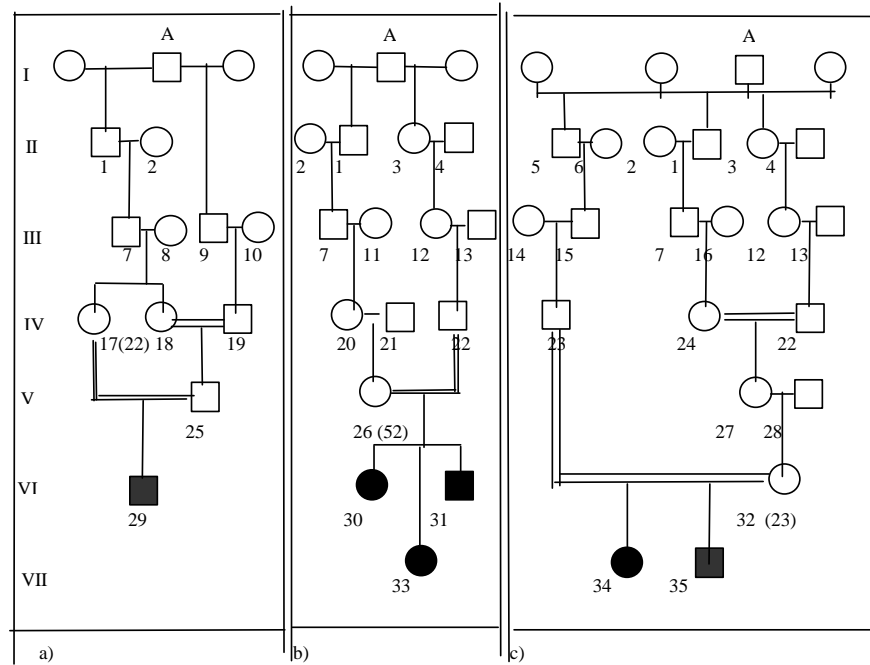

Fig. 2. Genetic analysis of calves with arthrogryposis. a) Genetic analysis of the progenitor and offspring of Bull 1 (V-25); b) genetic analysis of the progenitor and offspring of Bull 2 (IV-22); c) genetic analysis of the progenitor and offspring of Bull 3 (IV-23)

Same number in $\mathrm{a}, \mathrm{b}$ and $\mathrm{c}$ represents the same animal. The number of cows mated with each bull is within brackets.

Affected female, $\bigcirc$ affected male, $\bigcirc$ unaffected male, $\square$ unaffected female

in the hind limbs only. All affected buffalo calves had scant muscle development.

Histologically, the structure of the nervous system from the affected animals was unremarkable. The histological aspect of the muscles was normal as also were internal organs. The immunohistochemical analysis for BVD virus, performed in the CNS of one affected animal, was negative.

The 6 arthrogrypotic buffaloes were the offspring of phenotypically norma parents, and the defect appeared in both sexes. The analysis of breeding records demonstrated that 3 bulls (1 (V-25), 2 (IV-22) and 3 (IV-23)) and cows that produced affected calves were extremely inbred and had a 
Table 1. Distribution of calves with arthrogryposis in matings between the four bulls and cows of the herd, and artificial insemination during 2 years

\begin{tabular}{ccccccccc}
\hline \multirow{2}{*}{ Bull } & \multicolumn{3}{c}{1995} & & \multicolumn{3}{c}{1996} \\
\cline { 2 - 3 } \cline { 6 - 8 } & $\begin{array}{c}\text { Unaffected } \\
\text { calves }\end{array}$ & $\begin{array}{c}\text { Affected } \\
\text { calves }\end{array}$ & $\begin{array}{c}\text { Total of } \\
\text { calves }\end{array}$ & & $\begin{array}{c}\text { Unaffected } \\
\text { calves }\end{array}$ & $\begin{array}{c}\text { Affected } \\
\text { calves }\end{array}$ & $\begin{array}{c}\text { Total of } \\
\text { calves }\end{array}$ \\
\hline $1(\mathrm{~V}-25)$ & 6 & 0 & 6 & & 15 & 1 & 16 \\
$2(\mathrm{IV}-22)$ & 29 & 2 & 31 & & 20 & 1 & 21 \\
$3(\mathrm{IV}-23)$ & 7 & 2 & 9 & & 14 & 0 & 14 \\
4 & 28 & 0 & 28 & & 21 & 0 & 21 \\
5 & 8 & 0 & 8 & & 11 & 0 & 11 \\
Total & 72 & 4 & 82 & & 81 & 2 & 83
\end{tabular}

common ancestor (Bull A) (Fig. 2). The distribution of calves with arthrogryposis in matings between the 4 bulls and cows are shown in Table 1. The cows that were inseminated (Bull 5) or mated with the Bull 4 did not produce affected calves (Table 1).

\section{DISCUSSION}

Arthrogryposis was described as one of the most frequent defect of the musculoskeletal system and each distinct syndrome could be etiologically different (Greene et al. 1973). Analysis of the breeding records showed that most cows in the herd and Bulls 1 (V-25), 2 (IV-22) and 3 (IV-23), that produced affected progeny, had a common grandfather (Bull A). In the other way Bulls 4 and 5 , that did not produce affected progeny were non related with the herd. Furthermore, two other genetic diseases, hereditary suprabasilar acantholitic mecanobullous dermatosis (Riet-Correa et al. 1994) and a double muscle disease (Schild 2001) occur in the same herd which is significantly inbreed. These observations plus the fact that no medication was administered during pregnancy strongly suggest involvement of genetic factors in the etiology of the disease, probably an autosomal recessive trait. Furthermore, the herd management was made also with cattle that did not have deformed calves indicating that no exogenous factors or plants, that could cause the defect, were present in the grazing areas.

Bovine arthrogryposis commonly occurs as a syndrome associated with a single or multiple congenital defects (Leipold et al. 1970, Greene et al. 1973). In Charolais cattle the most common combined defect is palatoschisis, and in Hereford cattle palatoschisis or kyphoscoliosis have been observed (Greene et al. 1973). In all affected buffaloes arthrogryposis was observed as a single defect except for one that had additionally brachygnatia. This could be a result of differences in phenotypic expression of the defect. Hereditary arthrogryposis investigated in Canada, in Charolais calves from different farms, showed a wide variety of expressions. This probably occurs as a consequence of differences in the genetic background, action of modifying genes, or differences in an environmental component (Nawrot et al. 1980). In affected buffaloes of this study environmental influences were not relevant since the affected animals were from the same herd.
Arthrogryposis combined with hydranencephaly has been described in several breeds and was associated with Akabane virus infection (Konno et al. 1982, Konno \& Nakagawa 1982). In this case there is a large variety of microscopical lesions, including Wallerian degeneration, mild perivascular cuffing and encephalomyelitis, depending on the stage of the fetal CNS development at the time of the initial insult (Hartley \& Wanner 1974, Hartley et al. 1977, Konno et al. 1982). No evidence of a previous encephalomyelitis or Wallerian degeneration was detected in the affected buffaloes.

Negative results in immunohistochemical analysis for BVDV were expected in this outbreack. BVD virus may induce CNS lesions, mainly cerebellar hypoplasia in newborn cattle and sheep (Jubb et al. 1993), but those lesions are not observed in hereditary arthrogryposis.

Reduced number of motor neurons in ventral horns of the spinal cord and decreased muscular limb volume without significant CNS lesions in the affected buffaloes were observed in this study. Sporadic cases of arthrogryposis with multiple associated defects has been described without microscopic lesions in the brain, spinal cord and peripheral nerves, but with a possible reduction in the number of ventral horn neurons (Hartley \& Wanner 1974). Destruction of neurons in the foetus is a well documented component of arthrogryposis in cattle induced by infectious, physical and toxic neurotropic agents (Mayhew 1984).

It seems that arthrogryposis can have a wide variety of expressions and different type of lesions depending on the etiological agent, including genetic factors, and time of fetal development at the moment of the insult. The disease in buffaloes described here is an entity and differs from similar syndromes in cattle breeds by differences in phenotypic expression of the defect and/or by some differences in the central nervous system and muscular lesions.

Acknowledgements.- This work was supported by the Conselho Nacional de Desenvolvimento Científico e Tecnológico (CNPq) and Fundação de Amparo à Pesquisa do Rio Grande do Sul (FAPERGS). Thanks to Dr. Debora Cesar from DILAVE Miguel C. Rubino, Montevideo, Uruguay, who performed immunohistochemical analysis for BVD virus.

\section{REFERENCES}

Coverdale O.R. 1978. Congenital abnormalities in calves associated with Akabane virus and Aino virus. Aust. Vet. J. 54:151-152.

Edwards J.F., Livingston C.W., Chung S.I. \& Collisson E.C. 1989. Ovine arthrogryposis and Central Nervous System malformation associated with in utero Cache Valley virus infection: Spontaneous disease. Vet. Pathol. 26:33-39.

Greene H.J., Leipold H.W., Huston K. \& Huston K. 1973. Bovine congenital defects: Arthrogryposis and associated defects in calves. Am. J. Vet. Res. 34:887-891.

Hartley W.J. \& Wanner R.A. 1974. Bovine congenital artrhogryposis in New South Wales. Aust. Vet. J. 50:185-188.

Hartley W.J., Saram W.G., Della-Porta A.L., Snowdon W.A. \& Shepherd N.C. 1977. Pathology of congenital bovine epizootic arthrogryposis and hydranencephaly and its relationship to Akabane virus. Aust. Vet. J. 53: 319-325.

Jubb K.V.F., Kennedy P.C. \& Palmer N. 1993. Pathology of Domestic Animals. Vol. 1. 4th ed., p. 183-439. 
Konno S., Moriwaki M. \& Nakagawa M. 1982. Akabane disease in cattle: Congenital abnormalities caused by viral infection. Spontaneous disease. Vet. Pathol. 19: 246-266.

Konno S. \& Nakagawa M. 1982. Akabane disease in cattle: Congenital abnormalities caused by viral infection. Experimental disease. Vet. Pathol. 19: 267-279.

Leipold H.W., Cates W.F., Radostits O.M. \& Howell W.E. 1970. Arthrogryposis and associated defects in newborn calves. Am. J. Vet. Res. 31: 1367-1374.

Mayhew I.G. 1984. Neuromuscular Arthrogryposis Multiplex Congenita in a thoroughbred foal. Vet. Pathol. 21: 187-192.
Nawrot P.S., Howell W.E. \& Leipold H.W. 1980. Arthrogryposis: An inherited defect in newborn calves. Aust. Vet. J. 56:359-364.

Riet-Correa F., Barros S.S., Damé M.C. \& Peixoto P.V. 1994. Hereditary suprabasilar acantholytic mechanobullous dermatosis in Buffaloes (Bubalus bubalis). Vet. Pathol. 31:450-454.

Schild A.L. 2001. Defeitos congênitos, p. 19-40. In: Riet-Correa F, Schild A.L., Méndez M.C. \& Lemos R.A.A.L. Doenças de Ruminantes e Eqüinos. Vol. 1. 2nd ed. Varela Editora e Livraria, São Paulo.

Shupe J.L., Binns W., James L.F. \& Keeler R.F. 1967. Lupine, a cause of crooked calf disease. J. Am. Vet. Med. Assoc. 151:198-203. 